\title{
賛助会員名簿(2008. 1.25)
}

\begin{tabular}{|c|c|c|}
\hline (株)アールエフ & 三洋精密(株) & （株）東精エンジニアリング \\
\hline アイコクアルファ(株) & 三洋電機 (株) & 東北リコー(株) \\
\hline アイシン・エイ・ダブリュ(株) & 山陽特殊製鋼(株) & トクセンエ業(株) \\
\hline アイダエンジニアリング(株) & シャープ(株) & 杤木県産業技術センター \\
\hline 愛知製鋼 (株) & (株) 昭和サイエンス & (株)トプコン \\
\hline 旭ダイヤモンド工業(株)技術研究所 & 聖和精機 (株) & トヨタ自動車 (株) \\
\hline (株)アマダ & シグマ電子工業(株) & トヨタ自動車北海道(株) \\
\hline （株）天辻鋼球製作所 & シチズン時計(株) MHT開発本部 & (株)豊田自動織機 \\
\hline (株)アライドマテリアル & (株)島津製作所 & (株)トヨタプロダクションエンジニアリング \\
\hline イーグル工業(株) & (株) 新興製作所 & 独立行政法人造幣局 \\
\hline （株）飯沼ゲージ製作所 & 新世代加エシステム(株) & 中村留精密工業(株) \\
\hline 池上金型工業(株) & 新日本工機 (株) & (株)ナガセインテグレックス \\
\hline 池上通信機(株) & 新日本製鐵(株) & (株)長峰製作所 \\
\hline 石川島播磨重工業(株) & JFEスチール(株) & (株)ナノ \\
\hline イビデン(株) & (株)ジェイテクト & (株)南谷製作所 \\
\hline イビデンエンジニアリング(株) & (株)ジェイテクト & 日機電装(株) \\
\hline ウシオ電機 (株) & (株)スギノマシン & 日産自動車(株) 総合研究所 \\
\hline 臼井国際産業(株) & スピードファム(株) & （株）日進機械製作所 \\
\hline エス・オー・シー(株) & 住友金属鉱山(株) & 日東精工(株) \\
\hline (株) NSPM & 住友重機械工業(株) & (株)日平トヤマ 富山工場 \\
\hline エヌティー精密(株) & 住友スリーエム(株) & 日本エー・ディー・イー(株) \\
\hline NTN(株) & 住友電エハードメタル(株) & 日本ガイシ(株) \\
\hline (株)エリオニクス & 駿河精機(株) & 日本精工 (株) \\
\hline オーエスジー(株) & セイコーインスツル(株) & 日本電気 (株) \\
\hline オークマ(株) & セイコーエプソン(株) & 日本特殊陶業(株) \\
\hline オイレスエ業(株) & セイコープレシジョン(株) & 日本発条(株) \\
\hline 大阪精密機械(株) & 西部電機 (株) & (株) ニコン \\
\hline (財)大澤科学技術振興財団 & (株) 先端力学シミユレーション研究所 & 日本キスラー(株) \\
\hline 大塚精工(株) & ゼノー・テック(株) & （社）日本工作機械工業会 \\
\hline (株) 岡本工作機械製作所 & ソニーマニュファクチュアリングシステムズ(株) & （株）日本製鋼所 広島製作所 \\
\hline (株)小笠原プレシジョンラボラトリー & 大豊工業(株) & 日本電産トーソク(株) \\
\hline オムロン(株） & タカノ(株) & 日本電信電話(株)マイイロシステテムインデグレーション研究所 \\
\hline オムロン(株)草津事業所 & 高松機械工業(株) & 日本特殊研砥(株) \\
\hline オリンパス(株) & 多賀電気(株) & 日本ビクター(株) \\
\hline (株)音戸工作所 & (株)タムロン & 日本ファインテック(株) \\
\hline 花王(株) & (株)タンガロイ & 日本放送協会 \\
\hline 独立行政法人 科学技術振興機構 & ダイジェットエ業(株) & 日本ユニシス(株) \\
\hline (株)カシフジ & 大同化学工業(株) 奈良生産技術事業所 & (株)ネオス \\
\hline (株)化繊ノズル製作所 & ダイハツエ業(株) & (株) ノリタケコーテッドアブレーシブ \\
\hline (株)片桐製作所 & 中央精機 (株) & (株) ノリタケスーパーアブレーシブ \\
\hline (株)川邑研究所 & 中央精機 (株) & (株) ノリタケボンデッドアブレーシブ \\
\hline (株) 京二 & (株)チップトン & (株)ハーモニック·エイディ \\
\hline キヤハ(株) & 千代田(株) & ハイデンハイン(株) \\
\hline キヤノン(株) & 津田駒工業(株) & バンドー化学(株)生産技術センター \\
\hline キヤノンファインテック(株) & 津根精機(株) & (株)パイロットコーポレーション 平塚工場 \\
\hline クレノートン(株) & (株) TKX & パナソニック四国エレクトロニクス(株) \\
\hline 黒田精工 (株) & THK(株) & (株) 光合金製作所 \\
\hline 群馬県立群馬産業技術センター & THK (株)山形工場 & 日立金属(株)生産システム研究所 \\
\hline 経済産業省 特許庁 & テーラーホブソン(株) & 日立金属(株) NEOMAXカンパニー \\
\hline (財)工作機械技術振興財団 & (株)テオリック & (株) 日立情映テック \\
\hline (株) 構造計画研究所 & テクノハンズ(株) & (株)日立製作所 生産技術研究所 \\
\hline (株) 神戸製鋼所 技術開発本部 & (株) デンソー & (株)日立製作所 都市開発システムグループ \\
\hline 光洋機械工業(株) & トーヨーエイテック(株) & 日立造船(株) \\
\hline (株) 交洋製作所 & (株) 東海理化 & 日立ツール(株) \\
\hline (株) 小坂研究所 & (株) 東京精密 & 日立ビアメカニクス(株) \\
\hline コニカミノルタテクノロジーセンター(株) & 地方独立行政法人 東京都立産業技術研究センター & (株)ヒロテック \\
\hline コニカミノルタビジネステクノロジーズ(株) & (株)東芝 研究開発センター & (株)ビックツール \\
\hline （株）コロナ社 & (株)東芝 生産技術センター & (株)ピーエムティー \\
\hline 櫻井精技(株) & 東芝機械(株) & ファナック(株） \\
\hline サムタク(株) & (株) 東振精機 & ファナック(株）筑波工場 \\
\hline
\end{tabular}




\begin{tabular}{|c|c|c|}
\hline ファナック(株) 九州支社 & 松下電器産業(株) & (株) 森精機製作所 \\
\hline (株)フジキン & 松下電工 (株) & (株)安川電機 \\
\hline (株)不二越 & マツダ(株) & 安田工業（株） \\
\hline 不二越機械工業(株) & （株）マルトー & ヤマザキマザック(株) \\
\hline フジノン(株) & (株)ミズホ & (有)山正機械 \\
\hline 富士精工(株) & 三鷹光器 (株) & (株)山武 \\
\hline 富士通(株) & 三井精機工業(株)本社工場 & ヤマハ(株) \\
\hline (株) 藤原製作所 & 三菱電機(株)名古屋製作所 & ヤマハ発動機 (株) \\
\hline 扶桑化学工業(株) & 三菱電機(株)生産技術センター & (株) 彌満和製作所 \\
\hline 双葉電子工業(株) & 三菱電機メカトロニクスソフトウエア(株) & USOL東京(株) \\
\hline ブラザーエ業(株) & 三菱マテリアル(株)いわき製作所 & ユシロ化学工業(株) \\
\hline ホーコス(株) & 三菱マテリアル(株)明石製作所 & 豊精密工業(株) \\
\hline ホンダエンジニアリング(株) & 三菱レイヨン(株)生産技術研究所 & （株)リコー \\
\hline ボッシュ(株) & (株) 三宅 & リコーエレメックス(株) \\
\hline ポリテックジャパン(株) & 武蔵エンジニアリング(株) & ローレル精機(株) \\
\hline 牧野フライス精機(株) & (株) 村田製作所 野洲事業所 & (株)ワークス \\
\hline (株)牧野フライス製作所 & 明昌機工 (株) & (株) 和井田製作所 \\
\hline マコー(株) & (株)森川製作所 & \\
\hline
\end{tabular}

************* 新規入会の賛助会員 (2007年12月以降) $* * * * * * * * * * * * * * * * * * * * * * * * * * * * * * * * * * * * * * * * * * * * *$
$\mathrm{O}$ (株)長峰製作所
○(株)ワークス

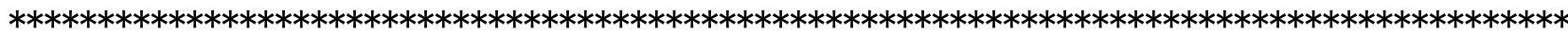

(1) * 賛助会員入会のお願い *

精密エ学会賛助会員には、以下のような特典がございます。是非、企業、団体各位のご入会をお願いいたします。

\section{賛助会員特典}

·毎月精密エ学会誌の配布があり、精密機械や生産技術に関する広範な知識を得ることができます。

·英文誌(季刊)の配布があります。

·講演会、講習会、見学会、展示会などの参加費が割引になります。

·学会ホームページの会員専用サービスの利用による学会研究者との個別交流が可能です。

・学会ホームページ・賛助会員リスト経由で賛助会員ホームページヘリンクしております。

·賛助Web級につきましては、特典が異なります。

\section{入会手続き}

「入会のしおり」は、本会ホームページの「学会紹介」に掲載しており、そこから入会手続きができます。

また、郵便、FAX等での手続きをご希望の場合は、下記の会員担当に資料、申込用紙をご請求下さい。

$$
\text { † 102-0073 }
$$

《お問い合わせ先 》

東京都千代田区九段北1-5-9九段誠和ビル2F

JSPEホームページURL:http://www.jspe.or.jp/

社団法人 精密工学会 会員係

TEL:03-5226-5191 FAX:03-5226-5192

e-mail:jspe_kaiin@jspe.or.jp

\section{学会事務局お問合せ先}

代表 jspejspe@jspe.or.jp

·総合案内

会員担当 jspe_kaiin@jspe.or.jp

- 入会·退会手続き

- 所属·連絡先等変更

. 学会誌·英文誌購読

・ バックナンバー販売, 複写サービス

·会費自動引き落とし

財務·会計担当 jspe_zaimu@jspe.or.jp

- 財務·会計

. 振込連絡
大会担当 jspe_taikai@jspe.or.jp

- 春季·秋季学術講演会

·卒業研究発表講演会

研究·国際交流担当 jspe_jigyo@jspe.or.jp

- 国際会議 (主催·共催)

- 専門委員会·分科会

講習会担当 jspe_koushu@jspe.or.jp

·講習会関係
出版担当 jspe_shuppan@jspe.or.jp

·会誌·英文誌への論文投稿

- 校閲状況確認

- 有料会告 (会誌)

広報·Web担当 jspe_koho@jspe.or.jp

- Webページ全般

・ バナー広告

. 有料会告 $($ Web $)$

- J-STAGE, NII関連 